\title{
Retraction Note to: Stickler syndrome report of a second Australian family
}

\author{
K. Kozlowski ${ }^{1}$ - G. Turner ${ }^{1}$
}

Published online: 10 July 2020

(C) Springer-Verlag GmbH Germany, part of Springer Nature 2020

Retraction Note to: Pediat. Radio1. 3, 230-234 (1975)

https://doi.org/10.1007/BF00975409

The Editors have retracted this article [1] as is it is not clear whether parental consent was provided for publication of the images and case. Given the age of the article we have been unable to verify this, therefore the article is no longer available online in order to protect the privacy of the individual. Both authors agree to this retraction.

\section{References}

Kozlowski K, Turner G (1975) Stickler Syndrome Report of a Second Australian Family. Pediat Radiol 3: 230-234

Publisher's note Springer Nature remains neutral with regard to jurisdictional claims in published maps and institutional affiliations.

The online version of the retraction notice can be found at https://doi.org/ 10.1007/BF00975409

\section{K. Kozlowski}

1 Department of Radiology and Children's Medical Research Foundation, Royal Alexandra Hospital for Children,

Sydney, Australia 